\title{
Review
}

\section{Genetic susceptibility to psoriasis: an emerging picture}

\author{
Rhodri LI Smith*, Richard B Warren†, Christopher EM Griffiths ${ }^{\ddagger}$ and Jane Worthington*
}

\begin{abstract}
Addresses: *ARC Epidemiology Unit, University of Manchester, Manchester, M13 9PT, UK. †Dermatological Sciences, Salford Royal Hospital, Manchester Academic Health Science Centre, UK. ‡University of Manchester, Manchester, M6 8HD, UK.
\end{abstract}

Correspondence: Jane Worthington. Email: Jane.Worthington@manchester.ac.uk.

\begin{abstract}
Psoriasis is recognized as a complex disease for which multiple genetic and non-genetic factors influence susceptibility. The major susceptibility locus resides in the MHC class I region and, until relatively recently, evidence for non-MHC loci was inconsistent. Like many common diseases, knowledge of the genetic basis of this condition has been advanced dramatically in recent times with the advent of genome-wide association studies using single nucleotide polymorphisms. Here, we give an overview of current knowledge of genetic risk factors for psoriasis and consider emerging studies that may further add to our understanding of the genetic basis of the disease.
\end{abstract}

\section{Introduction}

Psoriasis is a chronic immune-mediated skin disease that affects approximately $2 \%$ of the population worldwide [1]. Most cases (75\%) of chronic plaque psoriasis first present before the age of 40 years - known as early-onset or type I psoriasis - and late-onset cases presenting after the age of 40 years are classified as type II psoriasis [2]. The higher concordance rate in monozygotic twins (65 to $73 \%$ compared with 15 to $30 \%$ for dizygotic twins) suggests that psoriasis is a typical complex disease in which both genetic and environmental factors influence susceptibility [3-6]. Familybased analyses of patients with psoriasis and numerous population-based epidemiological studies have also confirmed the genetic basis of the disease [5,7-12]. From such studies, the heritability of psoriasis (a measure of the proportion of variability of a trait that is due to genetic factors) has been estimated to be 60 to $90 \%$ in the Caucasian population [10] and as high as 90 to $100 \%$ among Danish twins [13].

The importance of genes in psoriasis has long been recognized, and traditional approaches of family-based linkage studies and population-based candidate gene association studies have had some success in identifying genetic risk factors. Although psoriasis was not in the first wave of ground-breaking single nucleotide polymorphism
(SNP)-based genome-wide association studies (GWASs), which have signaled a new era in the identification of common variants determining susceptibility to common diseases, this approach is now being applied and it is timely to review current knowledge of psoriasis genetics. As evidenced by studies in other conditions, such as Crohn's disease, for which the key role of autophagy has been discovered using GWASs [14-16], advances in our understanding of the genetic markers involved in the phenotypic expression of this complex disorder will be crucial in providing the next generation of therapeutic targets for psoriasis.

\section{Psoriasis susceptibility loci identified before genome-wide association studies}

More than 35 years ago, associations with markers within the major histocompatibility complex (MHC) region on chromosome 6 were first identified for psoriasis [17] and, to this day, this locus remains the major susceptibility locus for psoriasis, accounting for 35 to $50 \%$ of Caucasian genetic susceptibility to early-onset psoriasis [18-20]. Strong associations have been found between familial psoriasis and human leukocyte antigen (HLA) class I genes, predominately $H L A-C w 6$, with a prevalence of up to $85 \%$ in early-onset patients compared with $15 \%$ in lateonset psoriasis and approximately $10 \%$ in the general population [2]. A consistent finding of linkage studies carried out in families with psoriasis was a broad peak over the MHC, designated PSORS1, leading to speculation that the locus could harbor effects additional to those already identified for $H L A-C w 6$. The strong linkage disequilibrium across this region adds to the difficulties of fine mapping and determination of causal effects. Uncertainty remains as to whether HLA-Cw6 is the causal variant, with other studies implicating different genes [21-24]. Recent evidence seems again to favor a role for HLA-Cw6 in both Caucasians [25] and Chinese families [26], but conditional analysis demonstrated that, although HLA-Cw6 was a major risk allele, it does not fully account for the PSORS1 linkage evidence. 
Whole-genome linkage screens of psoriasis [27-36] identified many potential susceptibility loci but, with the possible exception of PSORS1, fine mapping of these loci did not reveal convincing evidence for disease susceptibility genes, almost certainly because the studies were underpowered and many of the linkages were false positives. In contrast, recent well powered candidate gene association studies have been more fruitful. Notable successes include the replication of SNPs identified in the protein tyrosine phosphatase gene PTPN22 (rs3789604) [37], the asthma susceptibility gene $A D A M 33$ (rs597980) $[38,39]$ and in the kinase-associated protein CDKAL1 (rs6908425) [40] in a large US Caucasian cohort of 1,448 psoriasis patients and 1,385 controls [41]. Furthermore, strong association has also been reported between the interleukin gene IL15 and the disease in the Chinese Han population (g.596516, $P=5 \times 10^{-6}$ ) [42]. Interestingly, this polymorphism is not associated with psoriasis in any of the UK [43], German [44] or US Caucasian populations [41] investigated, and the minor allele frequency (MAF) for this SNP and others across IL15 differs quite strikingly between the populations, suggesting heterogeneity in the genetic susceptibility to psoriasis.

As well as being investigated for any potential functional role in the pathogenesis of psoriasis, candidates are increasingly targeted following association with related diseases. Although the $M H C$ locus has long been known to harbor the major susceptibility region for many inflammatory and autoimmune diseases, it is increasingly becoming apparent that psoriasis shares other non-MHC susceptibility loci with diseases such as type I diabetes and multiple sclerosis [45]. Of particular interest for psoriasis because of its co-morbidity with the disease are the regions of susceptibility shared with Crohn's disease. The prevalence of psoriasis is reported to be $9.6 \%$ among those affected with the chronic inflammatory bowel disease, compared with $2.2 \%$ of the controls [46]. Some recent candidate gene studies of psoriasis have adopted the approach of targeting reported Crohn's disease associations and have revealed many overlapping genetic loci common in both diseases [15,40]. One of these studies investigated 15 established Crohn's disease susceptibility loci in 1,256 psoriasis patients and 2,938 unrelated healthy controls. The same SNPs at three of these loci, 1q24, 6p22 (the CDKAL1 gene also associated with type II diabetes) and 21q22 [40], were significantly associated with psoriasis, with very similar effect sizes and the same risk alleles as those with Crohn's disease [14,47].

In addition to the well validated findings described above, there have been many conflicting reports of association and a frequent failure in replicating initial observations from candidate gene studies, probably reflecting low sample sizes and, therefore, low power to detect what are likely be relatively modest or weak effects. Candidate gene studies may also be considered to be limited as they tend to be hypothesis driven and based on existing knowledge of the disease and its pathogenesis. More recently, the technological advances that allow the high-throughput, accurate, simultaneous genotyping of hundreds of thousands of SNPs has bought a new era of genetic studies in which the whole genome can be systematically screened in a hypothesis-free manner, with the potential to uncover novel susceptibility markers in GWASs.

\section{Psoriasis susceptibility loci identified by genome-wide association studies}

The GWAS has recently become an extensively used approach as a result of advances in affordable highthroughput SNP genotyping technology and the availability of large patient cohorts and information on over four million validated SNPs with MAFs of at least $1 \%$, which are all publicly available on the HapMap database [48]. The HapMap Project also describes patterns of linkage disequilibrium (LD) between common polymorphisms across the genome, which crucially allows subsets of tagSNPs to be designed, ensuring that common variants will either be directly assayed or strongly correlated with an allele of a single tagSNP or tagSNP haplotype.

So far, four psoriasis GWASs have been reported in Caucasian populations [49-52], which have all identified novel psoriasis loci and validated established associations, with MHC- based SNPs in the proximity of the $H L A-C$ region proving most significant. The main findings of the first psoriasis GWAS, involving 1,446 US patients and 1,432 controls, reported association with four variants mapping to two non-MHC genes from the genotyping of 25,215 gene-centric SNPs: IL12B on chromosome $5 \mathrm{q}$ and $I L 23 R$, a gene encoding an interleukin receptor, on chromosome 1p of the broad PSORS7 locus, identified in early studies $[30,50]$.

Subsequent replication studies and more recent GWASs [49-53] have confirmed $I L 12 B$ and $I L 23 R$ as non-MHC genes associated with psoriasis risk. Furthermore, these polymorphisms have been investigated in studies of other diseases, with positive associations reported for inflammatory bowel disease [49,54], psoriatic arthritis [51], atopic dermatitis [55], asthma [51,56] and ankylosing spondylitis [57,58] but no association found with others, such as multiple sclerosis [59] and rheumatoid arthritis [60,61]. Indeed, the association of $I L 12 B$ and $I L 23 R$ with psoriasis has been strongly supported by the observation of increased IL23 in plaques of psoriasis and induction of psoriatic hyperplasia by injection of IL23 into mouse skin. The potential benefits of blocking the effects of the IL12 and IL23 cytokines have been clearly demonstrated, with the human monoclonal antibody ustekinumab found to be an effective treatment for severe psoriasis [62]. Two recently completed large randomized, double-blind, placebo- 
controlled clinical trials (PHOENIX I and II) of ustekinumab have demonstrated its effectiveness for treatment of moderate-to-severe psoriasis patients for up to 52 weeks [63] and 72 weeks of treatment [64]. Although the precise mechanism by which polymorphisms in $I L 12 B$ and $I L 23 R$ influence the disease process still requires further clarification, the associations and functional evidence suggest that the IL12/IL23 pathway has a key role in the pathogenesis of psoriasis.

The UK GWAS of 408,00o SNPs in an initial 318 psoriasis patients and 288 controls, followed by a validation stage using a further 519 patients and 528 controls, detected a novel association with a cluster of six correlated variants on chromosome 20q13 encompassing the transcription factor gene $Z N F 313$ [65]. One of these variants, rs495337, was subsequently validated in two independent replication sets of German and UK populations [65] with functional evidence supporting a role for $Z N F 313$ as a novel psoriasis susceptibility gene [65]. An independent GWAS of both psoriatic arthritis and psoriasis patients also reported novel susceptibility loci for psoriasis [51]. Genotyping 311,398 SNPs in an initial 223 US psoriasis patients and 519 Northern European controls, several novel associations were detected and validated in 577 US psoriasis patients and 737 controls. Polymorphisms in the gene encoding the Golgi complex protein COG6, the epidermal differentiation complex region of PSORS4, and a region on chromosome $15 \mathrm{q} 21$ all demonstrated strong evidence of association with psoriasis [51]. Recently, a US GWAS of 1,409 psoriasis cases and 1,436 controls, followed up in 5,048 patients and 5,041 controls, has reported further novel loci at $I L 23 A$, the zinc finger protein gene $T_{N F A I P}$, the TNFAIP 3 -interacting protein gene TNIP1, IL13 and IL4, suggesting a key role for $\mathrm{NF}-\mathrm{\kappa B}$ regulation and T-helper2 cells in psoriasis [52].

Further to these studies, the first large GWAS undertaken in a Chinese cohort (initial cohort: 1,139 cases and 1,132 controls; validation cohort: 5,182 cases and 6,516 controls) replicated the associations with MHC and $I L 12 B$ and detected a novel signal within the late cornified envelope (LCE) gene cluster on chromosome 1q21, which encodes key proteins implicated in epidermal terminal differentiation [66]. In conclusion, GWASs have been key in identifying common novel variants and validating existing polymorphisms of large or modest effect size that have been associated with psoriasis. With a large psoriasis cohort forming part of the Wellcome Trust Case Control Consortium [67] Phase II program, and results expected later this year, it is anticipated that further novel and validated associations will be reported for the disease.

\section{Copy number variants}

Following on from the abundance of GWAS data generated by SNP-based analysis, recent attention has switched to the variation of gene copy number across the genome, as it is increasingly becoming apparent that associations with common SNPs are unlikely to fully account for genetic susceptibility to complex diseases. Measuring the differences in copy number is complex, with many different types of variation possible, such as insertions and deletions. Consequently, much work is currently focused on refining this technology and characterizing the probes for these variants, so that they can be accurately detected and analyzed. Despite this, psoriasis is one disease in which associations have already been established with copy number variants. One study reported that an increased copy number of the $\beta$-defensin gene cluster on chromosome 8 , targeted because of its function of encoding antimicrobial peptides in the innate immune response - a key component of psoriasis pathogenesis - was associated with a significantly increased risk of the disease. This was demonstrated in independent Dutch and German psoriasis cohorts [68]. Furthermore, a linear regression conducted by the authors [68] on the combined cohorts used in the study suggested that each additional copy of the $\beta$-defensin gene cluster above two copies significantly increased relative risk by $34 \%$.

Another association between copy number variation and the disease has very recently been reported on chromosome 1q21, within the defined PSORS4 locus encompassing the late cornified envelope genes $L C E_{3} B$ and $L C E_{3} C$. A deletion of a region containing these genes was found to be associated with a significantly increased risk of psoriasis. This finding was further supported by single-point analysis of SNP rs4112788, which is in strong LD with the deletion and which also showed strong evidence of association with the disease [69].

\section{Conclusions}

GWASs have undoubtedly been a major breakthrough in investigating the genetic predisposition to complex disease, with hundreds of thousands of SNPs being genotyped in large sample sizes exceeding those for any previous methodology. Consequently, with statistical power greatly increased and study design further optimized, GWASs are unquestionably the preferred approach for investigating the genetics of complex diseases such as psoriasis, with rapid progress anticipated in the identification of susceptibility genes and loci. However, substantial replication and validation studies will be crucial in establishing these associations as risk factors for psoriasis. Larger cohorts will be pivotal for increasing power in identifying and validating causal variants of high and modest effect size. Furthermore, rare variants and small effect sizes underpinning genetic susceptibility of psoriasis will remain mostly undetected until sufficiently well powered studies are available, which will be achievable only through metaanalyses from extensive collaborations. Following on from this, the major challenge will be to identify the casual variants from these numerous association signals. Current 
strategies for this include re-sequencing and fine mapping using known and newly identified SNPs. The need for this may be reduced in the near future as efforts such as the 1000 Genomes Project [70] continue to add to our knowledge of human variation. These projects continue to drive technologies forward and costs down such that, in the not too distant future, strategies for the characterization of genetic risk factors for common disease may be based on genome-wide re-sequencing.

Knowledge of the genetic basis of psoriasis has advanced considerably in the past few years and looks set to continue at a great pace. The likely impact on treatment of patients with this condition is only beginning to be realized, but links between effective therapies and genetic associations are already emerging. For patients with severe psoriasis, there are two main treatment options, the immunosuppressive drugs such as methotrexate and the newer biological agents that target tumor necrosis factor alpha (TNF- $\alpha$ ), IL12/23 or $\mathrm{T}$-cell migration. Recent data have suggested that it may be possible to target the use of methotrexate depending on genotype in psoriasis and rheumatoid arthritis patients $[71,72]$. The impressive efficacy of ustekinumab (effective in $70 \%$ of patients at 12 weeks), which inhibits IL12/23, shows the enormous potential for targeting genetic loci discovered as part of GWASs and also indicates that loci that may seem to account for only a small amount of the total genetic variation of a condition can still be enormously effective when targeted as a treatment. A second drug that inhibits IL12/23 is ABT 874, which is currently undergoing phase III trials and shows early promise. Thus, we can look forward to a future of new and improved therapies administered in a targeted manner to individuals genetically predisposed to benefit from them.

\section{Competing interests}

RBW has been a consultant to or speaker for Abbott, Janssen Cilag, Merck Serono, Schering Plough and Wyeth, all of which manufacture biological drugs for psoriasis. CEMG has been a paid advisor to and/or has received research grants from Abbott, Janssen-Cilag, Leo, MerckSerono, Novartis, Pfizer, UCB Pharma and Wyeth, all of which manufacture drugs used in the treatment of psoriasis. The other authors declare that they have no competing interests.

\section{Authors' contributions}

RLS is lead author of this review.

\section{Acknowledgements}

The authors are supported in part by the Manchester National Institute for Health Research, Biomedical Research Centre.

\section{References}

1. Griffiths CE, Barker JN: Pathogenesis and clinical features of psoriasis. Lancet 2007, 370:263-271.
2. Henseler T, Christophers E: Psoriasis of early and late onset: characterization of two types of psoriasis vulgaris. $J \mathrm{Am}$ Acad Dermatol 1985, 13:450-456.

3. Bowcock AM, Cookson WO: The genetics of psoriasis, psoriatic arthritis and atopic dermatitis. Hum Mol Genet 2004, 13:R43-R55

4. Brandrup F, Holm N, Grunnet N, Henningsen K, Hansen HE: Psoriasis in monozygotic twins: variations in expression in individuals with identical genetic constitution. Acta Derm Venereol 1982, 62:229-236.

5. Farber EM, Bright RD, Nall ML: Psoriasis. A questionnaire survey of 2,144 patients. Arch Dermatol 1968, 98:248-259.

6. Lomholt G: Prevalence of skin diseases in a population; a census study from the Faroe Islands. Dan Med Bull 1964, 11:1-7

7. Watson W, Cann HM, Farber EM, Nall ML: The genetics of psoriasis. Arch Dermatol 1972, 105:197-207.

8. Morris A, Rogers M, Fischer G, Williams K: Childhood psoriasis: a clinical review of 1262 cases. Pediatr Dermatol 2001, 18:188-198.

9. Elder JT, Nair RP, Voorhees JJ: Epidemiology and the genetics of psoriasis. J Invest Dermatol 1994, 102:24S-27S.

10. Elder JT, Nair RP, Guo SW, Henseler T, Christophers E, Voorhees JJ: The genetics of psoriasis. Arch Dermatol 1994, 130:216-224.

11. Farber EM, Nail R: Epidemiology: natural history and genetics. In Psoriasis. 3rd edition. Edited by Roenigk HRJ, Maibach HI. New York: Marcel Dekker; 1998:107-157.

12. Rahman P, Elder JT: Genetic epidemiology of psoriasis and psoriatic arthritis. Ann Rheum Dis 2005, 64(Suppl 2):ii37ii39.

13. Brandrup $F$, Green A: The prevalence of psoriasis in Denmark. Acta Derm Venereol 1981, 61:344-346.

14. Parkes M, Barrett JC, Prescott NJ, Tremelling M, Anderson CA Fisher SA, Roberts RG, Nimmo ER, Cummings FR, Soars D, Drummond $\mathrm{H}$, Lees CW, Khawaja SA, Bagnall R, Burke DA, Todhunter CE, Ahmad T, Onnie CM, McArdle W, Strachan D, Bethel G, Bryan C, Lewis CM, Deloukas P, Forbes A, Sanderson J, Jewell DP, Satsangi J, Mansfield JC, Cardon L, et al.: Sequence variants in the autophagy gene IRGM and multiple other replicating loci contribute to Crohn's disease susceptibility. Nat Genet 2007, 39:830-832.

15. Rioux JD, Xavier RJ, Taylor KD, Silverberg MS, Goyette P Huett A, Green T, Kuballa P, Barmada MM, Datta LW, Shugart YY, Griffiths AM, Targan SR, Ippoliti AF, Bernard EJ, Mei L, Nicolae DL, Regueiro M, Schumm LP, Steinhart AH, Rotter JI, Duerr RH, Cho JH, Daly MJ, Brant SR: Genome-wide association study identifies new susceptibility loci for Crohn disease and implicates autophagy in disease pathogenesis. Nat Genet 2007, 39:596-604.

16. Massey DC, Parkes M: Genome-wide association scanning highlights two autophagy genes, ATG16L1 and IRGM, as being significantly associated with Crohn's disease. Autophagy 2007, 3:649-651.

17. Russell TJ, Schultes LM, Kuban DJ: Histocompatibility (HL-A) antigens associated with psoriasis. N Engl J Med 1972, 287:738-740.

18. Allen $\mathrm{MH}$, Veal $\mathrm{C}$, Faassen $\mathrm{A}$, Powis $\mathrm{SH}$, Vaughan $\mathrm{RW}$, Trembath RC, Barker JN: A non-HLA gene within the MHC in psoriasis. Lancet 1999, 353:1589-1590.

19. Asumalahti K, Laitinen $T$, Itkonen-Vatjus R, Lokki ML, Suomela $\mathrm{S}$, Snellman E, Saarialho-Kere U, Kere J: A candidate gene for psoriasis near HLA-C, HCR (Pg8), is highly polymorphic with a disease-associated susceptibility allele. Hum Mol Genet 2000, 9:1533-1542.

20. Mallon E, Bunce M, Wojnarowska F, Welsh K: HLA-CW*0602 is a susceptibility factor in type I psoriasis, and evidence Ala-73 is increased in male type I psoriatics. J Invest Dermatol 1997, 109:183-186.

21. Nair RP, Stuart $P$, Henseler T, Jenisch $S$, Chia NV, Westphal E, Schork NJ, Kim J, Lim HW, Christophers E, Voorhees JJ, Elder JT: Localization of psoriasis-susceptibility locus PSORS1 
to a 60-kb interval telomeric to HLA-C. Am J Hum Genet 2000, 66:1833-1844.

22. Balendran N, Clough RL, Arguello JR, Barber R, Veal C, Jones AB, Rosbotham JL, Little AM, Madrigal A, Barker JN, Powis $\mathrm{SH}$, Trembath RC: Characterization of the major susceptibility region for psoriasis at chromosome 6p21.3. J Invest Dermatol 1999, 113:322-328.

23. Oka A, Tamiya G, Tomizawa M, Ota M, Katsuyama $Y$, Makino $S$, Shiina T, Yoshitome M, lizuka M, Sasao $Y$, Iwashita K, Kawakubo Y, Sugai J, Ozawa A, Ohkido M, Kimura M, Bahram $\mathrm{S}$, Inoko $\mathrm{H}$ : Association analysis using refined microsatellite markers localizes a susceptibility locus for psoriasis vulgaris within a $111 \mathrm{~kb}$ segment telomeric to the HLA-C gene. Hum Mol Genet 1999, 8:2165-2170.

24. Veal CD, Capon F, Allen MH, Heath EK, Evans JC, Jones A, Patel S, Burden D, Tillman D, Barker JN, Trembath RC: Family-based analysis using a dense single-nucleotide polymorphism-based map defines genetic variation at PSORS1, the major psoriasis-susceptibility locus. Am J Hum Genet 2002, 71:554-564.

25. Nair RP, Stuart PE, Nistor I, Hiremagalore R, Chia NV, Jenisch S, Weichenthal M, Abecasis GR, Lim HW, Christophers E, Voorhees JJ, Elder JT: Sequence and haplotype analysis supports HLA-C as the psoriasis susceptibility 1 gene. Am $J$ Hum Genet 2006, 78:827-851.

26. Fan $X$, Yang $S$, Huang $W$, Wang $Z M$, Sun LD, Liang $Y H$, Gao $M$, Ren YQ, Zhang KY, Du WH, Shen YJ, Liu JJ, Zhang XJ: Fine mapping of the psoriasis susceptibility locus PSORS1 supports HLA-C as the susceptibility gene in the Han Chinese population. PLoS Genet 2008, 4:e1000038.

27. Trembath RC, Clough RL, Rosbotham JL, Jones AB, Camp RD, Frodsham A, Browne J, Barber R, Terwilliger J, Lathrop $\mathrm{GM}$, Barker JN: Identification of a major susceptibility locus on chromosome $6 p$ and evidence for further disease loci revealed by a two stage genome-wide search in psoriasis. Hum Mol Genet 1997, 6:813-820.

28. Nair RP, Henseler T, Jenisch S, Stuart P, Bichakjian CK, Lenk W, Westphal E, Guo SW, Christophers E, Voorhees JJ, Elder JT: Evidence for two psoriasis susceptibility loci (HLA and $17 q)$ and two novel candidate regions (16q and 20p) by genome-wide scan. Hum Mol Genet 1997, 6:1349-1356.

29. Lee $Y A$, Ruschendorf $F$, Windemuth $C$, Schmitt-Egenolf $M$, Stadelmann A, Nurnberg G, Stander M, Wienker TF, Reis A, Traupe H: Genomewide scan in German families reveals evidence for a novel psoriasis-susceptibility locus on chromosome 19p13. Am J Hum Genet 2000, 67:1020-1024.

30. Veal CD, Clough RL, Barber RC, Mason S, Tillman D, Ferry B, Jones $A B$, Ameen $M$, Balendran N, Powis $S H$, Burden AD, Barker JN, Trembath RC: Identification of a novel psoriasis susceptibility locus at $1 p$ and evidence of epistasis between PSORS1 and candidate loci. J Med Genet 2001, 38:7-13.

31. Zhang K, Calabrese P, Nordborg M, Sun F: Haplotype block structure and its applications to association studies: power and study designs. Am J Hum Genet 2002, 71:13861394

32. Tomfohrde J, Silverman A, Barnes R, Fernandez-Vina MA, Young M, Lory D, Morris L, Wuepper KD, Stastny P, Menter A: Gene for familial psoriasis susceptibility mapped to the distal end of human chromosome 17q. Science 1994, 264:1141-1145.

33. Samuelsson $L$, Enlund $F$, Torinsson $A$, $Y h r ~ M$, Inerot $A$, Enerback C, Wahlstrom J, Swanbeck G, Martinsson T: A genome-wide search for genes predisposing to familial psoriasis by using a stratification approach. Hum Genet 1999, 105:523-529.

34. Enlund $F$, Samuelsson L, Enerback $C$, Inerot A, Wahlstrom J, Yhr M, Torinsson A, Riley J, Swanbeck G, Martinsson T: Psoriasis susceptibility locus in chromosome region $3 q 21$ identified in patients from southwest Sweden. Eur J Hum Genet 1999, 7:783-790.

35. Karason A, Gudjonsson JE, Jonsson HH, Hauksson VB, Runarsdottir EH, Stefansson K, Valdimarsson H, Gulcher JR: Genetics of psoriasis in Iceland: evidence for linkage of subphenotypes to distinct loci. J Invest Dermatol 2005 124:1177-1185

36. Lesueur F, Lefevre C, Has C, Guilloud-Bataille M, Oudot T, Mahe E, Lahfa M, Mansouri S, Mosharraf-Olmolk H, Sobel E, Heath S, Lathrop M, Dizier MH, Prud'homme JF, Fischer J: Confirmation of psoriasis susceptibility loci on chromosome 6p21 and 20p13 in French families. $J$ Invest Dermatol 2007, 127:1403-1409.

37. Smith RL, Warren RB, Eyre S, Ke X, Young HS, Allen M, Strachan D, McArdle W, Gittins MP, Barker JN, Griffiths CE, Worthington J: Polymorphisms in the PTPN22 region are associated with psoriasis of early onset. $\mathrm{Br} J$ Dermatol 2008, 158:962-968.

38. Lesueur F, Oudot T, Heath S, Foglio M, Lathrop M, Prud'homme JF, Fischer J: ADAM33, a new candidate for psoriasis susceptibility. PLOS ONE 2007, 2:e906.

39. Siroux V, Bouzigon E, Dizier MH, Pin I, Demenais F, Kauffmann F: Replication of association between ADAM33 polymorphisms and psoriasis. PLOS ONE 2008, 3:e2448.

40. Wolf N, Quaranta M, Prescott NJ, Allen M, Smith R, Burden AD, Worthington J, Griffiths CE, Mathew CG, Barker JN, Capon F, Trembath RC: Psoriasis is associated with pleiotropic susceptibility loci identified in type II diabetes and Crohn disease. J Med Genet 2008, 45:114-116.

41. Li Y, Liao W, Chang M, Schrodi SJ, Bui N, Catanese JJ, Poon A, Matsunami N, Callis-Duffin KP, Leppert MF, Bowcock AM, Kwok PY, Krueger GG, Begovich AB: Further genetic evidence for three psoriasis-risk genes: ADAM33, CDKAL1, and PTPN22. J Invest Dermatol 2009, 129:629-634.

42. Zhang $X J$, Yan KL, Wang ZM, Yang S, Zhang GL, Fan X, Xiao $F L$, Gao M, Cui Y, Wang PG, Sun LD, Zhang KY, Wang B, Wang DZ, Xu SJ, Huang W, Liu JJ: Polymorphisms in interleukin-15 gene on chromosome 4q31.2 are associated with psoriasis vulgaris in Chinese population. $J$ Invest Dermatol 2007, 127:2544-2551.

43. Smith RL, Eyre S, Warren RB, Young HS, Griffiths CE, Worthington $\mathrm{J}$ : No association between polymorphisms in the interleukin-15 gene and early-onset psoriasis in a UK cohort suggests heterogeneity for this susceptibility locus identified in Chinese psoriasis patients. $J$ Invest Dermatol 2008, 128:2904-2905.

44. Weger W, Hofer A, Wolf $P$, El-Shabrawi $Y$, Renner W, Kerl H Salmhofer W: Role of the interleukin $1596516 \mathrm{~A}>\mathrm{T}$ and IL15 96330C>A gene polymorphisms in Caucasian patients with chronic plaque psoriasis. J Dermatol Sci 2008, 51:147-149.

45. Becker KG, Simon RM, Bailey-Wilson JE, Freidlin B, Biddison WE, McFarland HF, Trent JM: Clustering of non-major histocompatibility complex susceptibility candidate loci in human autoimmune diseases. Proc Natl Acad Sci USA 1998 95:9979-9984

46. Lee FI, Bellary SV, Francis C: Increased occurrence of psoriasis in patients with Crohn's disease and their relatives. Am J Gastroenterol 1990, 85:962-963.

47. Wellcome Trust Case Control Consortium: Genome-wide association study of 14,000 cases of seven common diseases and 3,000 shared controls. Nature 2007, 447:661-678.

48. International HapMap Project [http://www.hapmap.org]

49. Capon F, Di MP, Szaub J, Prescott NJ, Dunster C, Baumber L, Timms K, Gutin A, Abkevic V, Burden AD, Lanchbury J, Barker $\mathrm{JN}$, Trembath RC, Nestle FO: Sequence variants in the genes for the interleukin-23 receptor (IL23R) and its ligand (IL12B) confer protection against psoriasis. Hum Genet 2007, 122:201-206

50. Cargill M, Schrodi SJ, Chang M, Garcia VE, Brandon R, Callis KP, Matsunami N, Ardlie KG, Civello D, Catanese JJ, Leong DU, Panko JM, McAllister LB, Hansen CB, Papenfuss J, Prescott SM, White TJ, Leppert MF, Krueger GG, Begovich AB: A large-scale genetic association study confirms IL12B and leads to the identification of IL23R as psoriasis-risk genes. Am J Hum Genet 2007, 80:273-290.

51. Liu C, Batliwalla F, Li W, Lee A, Roubenoff R, Beckman E, Khalili H, Damle A, Kern M, Furie R, Dupuis J, Plenge RM, Coenen MJ, Behrens TW, Carulli JP, Gregersen PK: Genome- 
wide association scan identifies candidate polymorphisms associated with differential response to anti-TNF treatment in rheumatoid arthritis. Mol Med 2008, 14:575-581.

52. Nair RP, Duffin KC, Helms C, Ding J, Stuart PE, Goldgar D, Gudjonsson JE, Li Y, Tejasvi T, Feng BJ, Ruether A, Schreiber S, Weichenthal M, Gladman D, Rahman P, Schrodi SJ, Prahalad S, Guthery SL, Fischer J, Liao W, Kwok PY, Menter A, Lathrop GM, Wise CA, Begovich AB, Voorhees JJ, Elder JT, Krueger GG, Bowcock AM, Abecasis GR: Genome-wide scan reveals association of psoriasis with IL-23 and NF-kappaB pathways. Nat Genet 2009, 41:199-204.

53. Smith RL, Warren RB, Eyre S, Ho P, Ke X, Young HS, Griffiths $\mathrm{CE}$, Worthington $\mathrm{J}$ : Polymorphisms in the IL-12beta and IL-23R genes are associated with psoriasis of early onset in a UK cohort. J Invest Dermatol 2008, 128:1325-1327.

54. Duerr RH, Taylor KD, Brant SR, Rioux JD, Silverberg MS, Daly MJ, Steinhart AH, Abraham C, Regueiro M, Griffiths A, Dassopoulos T, Bitton A, Yang H, Targan S, Datta LW, Kistner EO, Schumm LP, Lee AT, Gregersen PK, Barmada MM, Rotter $\mathrm{JI}$, Nicolae DL, Cho JH: A genome-wide association study identifies IL23R as an inflammatory bowel disease gene. Science 2006, 314:1461-1463.

55. Tsunemi $Y$, Saeki H, Nakamura K, Sekiya T, Hirai K, Fujita $H$, Asano N, Kishimoto M, Tanida Y, Kakinuma T, Mitsui H, Tada Y, Wakugawa $\mathrm{M}$, Torii $\mathrm{H}$, Komine $\mathrm{M}$, Asahina A, Tamaki $\mathrm{K}$ : Interleukin-12 p40 gene (IL12B) 3'-untranslated region polymorphism is associated with susceptibility to atopic dermatitis and psoriasis vulgaris. J Dermatol Sci 2002, 30:161-166.

56. Randolph AG, Lange $C$, Silverman EK, Lazarus R, Silverman ES, Raby B, Brown A, Ozonoff A, Richter B, Weiss ST: The IL12B gene is associated with asthma. Am J Hum Genet 2004, 75:709-715.

57. Rueda B, Orozco G, Raya E, Fernandez-Sueiro JL, Mulero J, Blanco FJ, Vilches C, Gonzalez-Gay MA, Martin J: The IL23R Arg381GIn non-synonymous polymorphism confers susceptibility to ankylosing spondylitis. Ann Rheum Dis 2008, 67:1451-1454.

58. Rahman $\mathrm{P}$, Inman RD, Gladman DD, Reeve JP, Peddle L, Maksymowych WP: Association of interleukin-23 receptor variants with ankylosing spondylitis. Arthritis Rheum 2008, 58:1020-1025

59. Begovich AB, Chang M, Caillier SJ, Lew D, Catanese JJ, Wang $\mathrm{J}$, Hauser SL, Oksenberg JR: The autoimmune diseaseassociated IL12B and IL23R polymorphisms in multiple sclerosis. Hum Immunol 2007, 68:934-937.

60. Chang M, Saiki RK, Cantanese JJ, Lew D, van der Helm-van Mil AH, Toes RE, Huizinga TW, Ardlie KG, Criswell LA, Seldin MF, Amos CI, Kastner DL, Gregersen PK, Schrodi SJ, Begovich $A B$ : The inflammatory disease-associated variants in IL12B and IL23R are not associated with rheumatoid arthritis. Arthritis Rheum 2008, 58:1877-1881.

61. Orozco G, Gonzalez-Gay MA, Paco L, Lopez-Nevot MA, Guzman M, Pascual-Salcedo D, Balsa A, Martin J: Interleukin 12 (IL12B) and interleukin 12 receptor (IL12RB1) gene polymorphisms in rheumatoid arthritis. Hum Immunol 2005, 66:710-715.

62. Krueger GG, Langley RG, Leonardi C, Yeilding N, Guzzo C, Wang Y, Dooley LT, Lebwohl M: A human interleukin-12/23 monoclonal antibody for the treatment of psoriasis. $N$ Engl J Med 2007, 356:580-592.
63. Papp KA, Langley RG, Lebwohl M, Krueger GG, Szapary P, Yeilding N, Guzzo C, Hsu MC, Wang Y, Li S, Dooley LT, Reich $\mathrm{K}$ : Efficacy and safety of ustekinumab, a human interleukin-12/23 monoclonal antibody, in patients with psoriasis: 52-week results from a randomised, double-blind, placebo-controlled trial (PHOENIX 2). Lancet 2008, 371:1675-1684

64. Leonardi CL, Kimball AB, Papp KA, Yeilding N, Guzzo C, Wang Y, Li S, Dooley LT, Gordon KB: Efficacy and safety of ustekinumab, a human interleukin-12/23 monoclonal antibody, in patients with psoriasis: 76-week results from a randomised, double-blind, placebo-controlled trial (PHOENIX 1). Lancet $2008,371: 1665-1674$

65. Capon F, Bijlmakers MJ, Wolf N, Quaranta M, Huffmeier U, Allen M, Timms K, Abkevich V, Gutin A, Smith R, Warren RB, Young HS, Worthington J, Burden AD, Griffiths CE, Hayday A, Nestle FO, Reis A, Lanchbury J, Barker JN, Trembath RC: Identification of ZNF313/RNF114 as a novel psoriasis susceptibility gene. Hum Mol Genet 2008, 17:1938-1945

66. Zhang XJ, Huang W, Yang S, Sun LD, Zhang FY, Zhu QX, Zhang FR, Zhang C, Du WH, Pu XM, Li H, Xiao FL, Wang ZX, Cui Y, Hao F, Zheng J, Yang XQ, Cheng $H$, He CD, Liu XM, Xu LM, Zheng HF, Zhang SM, Zhang JZ, Wang HY, Cheng YL, Ji $\mathrm{BH}$, Fang QY, Li YZ, Zhou FS, et al.: Psoriasis genome-wide association study identifies susceptibility variants within LCE gene cluster at 1q21. Nat Genet 2009, 41:205-210.

67. Wellcome Trust Case Control Consortium [http://www.wtccc. org.uk]

68. Hollox EJ, Huffmeier U, Zeeuwen PL, Palla R, Lascorz J, Rodijk-Olthuis $D$, van de Kerkhof PC, Traupe $H$, de JG, den HM, Reis A, Armour JA, Schalkwijk J: Psoriasis is associated with increased beta-defensin genomic copy number. Nat Genet 2008, 40:23-25.

69. de Cid R, Riveira-Munoz E, Zeeuwen PL, Robarge J, Liao W, Dannhauser EN, Giardina E, Stuart PE, Nair R, Helms C, Escaramis G, Ballana E, Martin-Ezquerra G, den HM, Kamsteeg M, Joosten I, Eichler EE, Lazaro C, Pujol RM, Armengol L, Abecasis G, Elder JT, Novelli G, Armour JA, Kwok PY, Bowcock A, Schalkwijk J, Estivill X: Deletion of the late cornified envelope LCE3B and LCE3C genes as a susceptibility factor for psoriasis. Nat Genet 2009, 41:211-215.

70. 1000 Genomes Project : A Deep Catalog of Human Genetic Variation [http://www.1000genomes.org]

71. Warren RB, Smith RL, Campalani E, Eyre S, Smith CH, Barker JN, Worthington J, Griffiths CE: Genetic variation in efflux transporters influences outcome to methotrexate therapy in patients with psoriasis. J Invest Dermatol 2008, 128:19251929.

72. Hider SL, Thomson W, Mack LF, Armstrong DJ, Shadforth M, Bruce IN: Polymorphisms within the adenosine receptor $2 \mathrm{a}$ gene are associated with adverse events in RA patients treated with MTX. Rheumatology (Oxford) 2008, 47:11561159.

Published: 22 July 2009

doi:10.1186/gm72

(c) 2009 BioMed Central Ltd 